\title{
STUDI KASUS: KARAKTERISTIK ANTISIPASI EKSPLORATIF
}

\author{
Erfan Yudianto \\ Dosen Program Studi Pendidikan Matematika FKIP Universitas Jember \\ Jalan Kalimantan 37 Kampus Tegalboto Jember. \\ erfanyudi@unej.ac.id.
}

\begin{abstract}
ABSTRAK
Kesulitan siswa dalam menyelesaikan masalah integral kemungkinan besar dikarenakan kesalahan siswa dalam memahami soal. Tidak sampai disana saja, kesalahan memahami soal dimungkinkan karena antisipasi yang dilakukan siswa salah. Jika ada siswa dengan kemampuan tinggi, maka sebaiknya guru memperhatikan antisipasi yang dilakukannya sehingga siswa lain dapat belajar dari antisipasi yang dilakukan siswa kemampuan tinggi itu. Tes yang dilakukan kepada siswa NV ini merupakan tes integral dan hasil yang diperoleh yaitu karakteristik dari antisipasi ekploratif NV. Karakteristik antisipasi eksploratif yaitu (1) membaca soal lebih dari satu kali, (2) menemukan hal yang ditanyakan dan hal yang diketahui, (3) menguraikan soal secara rinci, (4) menggabungkan kriteria-kriteria yang diketahui, dan (5) memecahkan soal dengan mempertimbangkan alternatif penyelesaian
\end{abstract}

Kata Kunci: Antisipasi, antisipasi eksploratif, integral

\begin{abstract}
Student difficulties in solving the problem integral likely due to students' mistakes in understanding the problem. Not until there, understand about possible errors due to anticipation student is doing wrong. If there are students with high ability, then the teachers should pay attention to the anticipation of his accomplishments so other students can learn from the anticipation of high ability students who do it. Tests were carried out to the students NV is an integral test and the results obtained are characteristic of anticipation explorative NV. Characteristics anticipation explorative are (1) read the questions more than once, (2) finding things to ask and things unknown, (3) explore the matter in detail, (4) combining the criteria are known, and (5) solve the problem by considering an alternative solution
\end{abstract}

Keyword: Anticipation, explorative anticipation, integral

\section{Pendahuluan}

Kemampuan siswa dalam

smart solution. Cara-cara yang ditawarkan menyelesaikan masalah di Kabupaten ini merupakan cara yang "efektif" untuk Jember masih relatif rendah. Hal ini menjawab pertanyaan-pertanyaan singkat ditemui oleh peneliti pada siswa kelas XII yang mengikuti bimbingan belajar di suatu lembaga formal. Sebagian besar siswa terbiasa menggunakan cara-cara cepat yang biasa dikenal dengan sebutan versi Ujian Nasional (UN). Kelemahannya cara ini yaitu siswa tidak mengetahui secara detail langkah-langkah pengerjaan soal itu sehingga siswa fokus pada hasil saja. Pengetahuan yang dimiliki siswa 
tidak sempat dieksplor bagaimana mencapai suatu jawaban yang tepat.

Anderson (1993) mengatakan bahwa pengetahuan yang dimiliki siswa nantinya akan melalui tindakan deklaratif, kesadaran kemudian kontrol. Pada "control" inilah yang akan membuka jalan dalam proses prosedural. Selanjutnya ia berpendapat bahwa pengetahuan deklaratif membentuk dasar dari transfer pengetahuan. Hal ini dirasa perlu untuk mengajarkan antisipasi kepada siswa dalam menyelesaikan suatu masalah matematika. Sejalan dengan itu, Lim (2006: 105) mengatakan bahwa antisipasi dalam menyikapi masalah sangat diperlukan dalam melakukan tindakan mental untuk menyelesaikan masalah matematika. Perlunya antisipasi siswa di sekolah juga diungkap oleh Yudianto \& Sunardi (2015: 206) bahwa untuk menghadapi masalah di sekolah siswa diharapkan mampu mengantisipasi untuk mendapatkan hasil yang tepat. Sejalan dengan itu Yudianto mengatakan bahwa, antisipasi harus dimiliki siswa dalam menyelesaikan masalah matematika dengan tujuan untuk memperoleh jawaban eksak yang bernilai benar. Sehingga dapat disimpulkan bahwa antisipasi merupakan aktivitas baik mental maupun fisik yang dipikirkan siswa untuk mengatasi suatu keadaan yang belum pasti. Yang dimaksud keaadaan yang belum pasti ini yaitu proses apa dan bagaimana cara yang akan dilakukan siswa untuk menyelesaikan masalah yang diberikan. Kelebihannya yaitu siswa sudah bisa menduga hasil yang akan diperoleh. Sehingga semakin sering siswa melakukan antisipasi dalam menyelesaikan masalah maka semakin banyak juga alternatif-alternatif pemecahan masalah yang akan dilakukan siswa.

Lim (2006) mengklasifikasikan antisipasi menjadi lima bagian yaitu (1) antisipasi impulsif, (2) antisipasi kaku, (3) antisipasi eksploratif, (4) antisipasi Analitik, dan (5) antisipasi terinternalisasi. Selanjutnya dalam hasil penelitiannya, Lim (2006) mengatakan bahwa antisipasi analitik dan antisipasi eksploratif merupakan antisipasi yang baik yang harus dilakukan siswa dalam menyelesaikan suatu masalah matematika. Antisipasi eksploratif didefinisikan sebagai cara berpikir dimana siswa menggali ide untuk mendapatkan pemahaman yang lebih baik dari suatu masalah (mengantisipasi secara eksploratif/mau coba-coba/tidak kaku). Antisipasi ini disimpulkan ketika siswa melakukan tindakan untuk mendapatkan penyelesaian dari suatu masalah matematika. Ini berarti siswa yang melakukan antisipasi eksploratif memiliki waktu yang cukup lama dalam mengolah 
informasi yang sesuai untuk menyelesaikan masalah yang dihadapi.

Berbicara matematika di jenjang SMA kelas XII pada pertemuan pertama di tahun pelajaran baru, siswa langsung belajar masalah Integral. Integral merupakan sub pokok bahasan matematika yang dirasa sulit oleh sebagian siswa. Sejalan dengan itu Ramdani (2012) melaporkan hasil try out Ujian Nasional pada tahun 2000 dengan peserta 879 siswa SMA di kota Bandung menunjukkan bahwa siswa yang mampu menjawab benar untuk konsep integral hanya $30,22 \%$, sedangkan try out Ujian Nasional pada tahun 2011 yang diikuti oleh 1678 siswa hanya 6,7\% siswa yang mampu menjawab benar.

Berdasarkan hal-hal di atas, peneliti ingin mengungkap karakteritik yang dimiliki siswa yang mengantisipasi secara eksploratif. Hal ini diperlukan sebagai informasi kepad siswa bahwa pentingnya berpikir secara eksploratif pada waktu tertentu. Oleh karena itu pada penelitian ini peneliti tertarik untuk mengungkap karakteristik antisipasi eksploratif siswa dalam menyelesaikan masalah integral.

\section{Metode Penelitian}

Penelitian studi kasus ini bertujuan untuk memperoleh karakteristik antisipasi eksploratif. Pendekatan yang digunakan adalah pendekatan kualitatif. Jika dilihat dari tujuan penelitian, maka penelitian ini merupakan penelitian deskriptif sedangkan jika dilihat dari tujuan spesifiknya yaitu mengeksplorasi apa yang dipikirkan dan dilakukan oleh siswa, maka penelitian ini merupakan penelitian eksploratif. Jadi jenis penelitian pada studi kasus ini adalah deskriptif eksploratif.

Subjek penelitian ini adalah seorang siswa yaitu siswa SMA kelas XII dengan kriteria siswa sudah belajar/sudah menerima masalah integral di kelas XII semester I. Hal ini dikarenakan materi integral sudah diterima siswa di kelas XII pada bab I. kemampuan seorang siswa ini dipilih kemampuan matematika tinggi. Kemampuan ini diperoleh dari tes kemampuan matematika berdasarkan soalsoal Ujian Nasional tahun 2015 yang sudah dimodifikasi menjadi soal uraian.

\section{Hasil dan Pembahasan}

Permasalahan yang diberikan kepada siswa merupakan soal integral terkait luas daerah. Berikut soal yang diberikan kepada siswa.

Tentukan luas daerah yang dibatasi kurva

$$
y=x^{2}-4
$$

dan sumbu X pada interval $-3 \leq x \leq 0$

Siswa dengan inisial NV menyelesaikan masalah di atas sebagai berikut. 

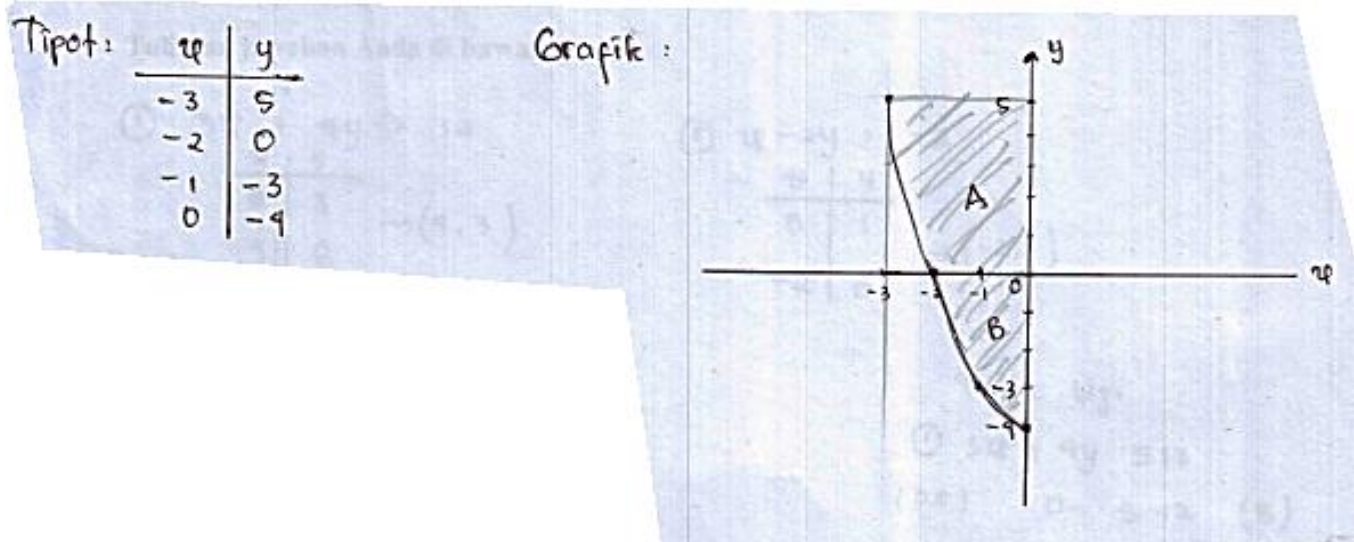

Gambar 1. Hasil Pekerjaan NV tahap awal

Pada tahap awal NV membuat titik potong dengan cara mensubstitusi semua interval yaitu $-3 \leq x \leq 0 \quad$ kemudian mensketsa titik potong-titik potong tersebut pada bidang katesius. Sehingga terlihat seperti gambar 1. Hasil sketsa grafik, NV memberi identitas baru pada grafiknya yaitu pada arsiran teratas sebagai A (luasan A) dan pada bagian bawah yaitu B (luasan B).

$$
\begin{aligned}
L A & =\int_{-3}^{0} \varphi^{2}-4 \\
& =\left(\frac{\varphi^{3}}{3}-4 \varphi\right)_{-3}^{0} \\
& =0-\left(\frac{(-3)^{3}}{3}-4(-3)\right) \\
& =0-\left(-\frac{27}{3}+12\right) \\
& =0-(-9+12) \\
& =0-(3)=-3
\end{aligned}
$$

Gambar 2. Perhitungan Luas A

Pada gambar 2, NV melakukan perhitungan secara prosedural untuk perhitungan luas A (bagian atas). Saat ditanyakan kenapa pekerjaannya seperti itu? (peneliti mengecek pengetahuan siswa, apakah NV akan menjawab berdasarkan rumus atau tidak). NV ternyata menjawab tidak berdasarkan rumus tetapi menjelaskan melalui sketsa grafik pada gambar 1. Ia terlihat memahami secara detail pada permasalahan ini. Lebih lanjut NV menjelaskan bahwa setelah diarsir (menunjuk sketsa grafik) NV menceritakan bahwa pada arsiran teratas (di atas sumbu $\mathrm{X}$ ) bernilai positif. Ini berarti NV tidak sekedar menggunakan rumus yang ada tetapi ia mengotak atik informasi-informasi yang sudah disediakan oleh soal kemudian membandingkan bagian-bagian mana yang akan digunakan terlebih dahulu. Selanjutnya NV menjelaskan cara menghitung luas daerah A berdasarkan gambar 2. Penjelasan NV sangat detail sehingga diperoleh hasil -3. Kemudian NV melanjutkan perhitungan pada daerah B. 


$$
\begin{aligned}
L_{B} & =-\int_{-2}^{0} \varphi^{2}-4 \\
& =-\left(\frac{\varphi^{3}}{3}-4 \varphi\right)_{-2}^{0} \\
& =-\left((0)-\left(\frac{(-2)^{3}}{3}-4(-2)\right)\right) \\
& =-\left((0)-\left(-\frac{8}{3}+8\right)\right) \\
& =-\left((0)-\left(\frac{16}{3}\right)\right) \\
& =-\left(-\frac{16}{3}\right)=\frac{16}{3}
\end{aligned}
$$

Gambar 3. Perhitungan luas B

Pada gambar 3, NV menjelaskan bahwa rumus yang digunakan yaitu harus dikalikan dengan “_“, ia beralasan karena gambarnya ada di bawah sumbu $X$ sehingga jika tidak ingin merubah batas atas dan batas bawahnya makan cukup dikalikan dengan negatif. Ia menjelaskan contoh-contoh yang menunjukkan bahwa hubungan antara tanda negatif dan batas itu benar. Sehingga saat batas di "tukar" yaitu 0 menjadi batas bawah dan -2 menjadi batas atas, tanpa memberikan tanda negatif di depannya, maka nilai yang akan diperoleh sama. Selanjutnya NV menjumlahkan hasil dari perhitungan luas daerah A dan luas daerah B seperti pada gambar 4 berikut.

$$
\begin{aligned}
L & =A+B \\
& =-3+\frac{16}{3}=\frac{7}{3}
\end{aligned}
$$

Gambar 4. Perhitungan luas total
Penjelasan NV secara panjang, lebar dan detail ditambah lagi dengan ilustrasi-ilustrasi gambar serta argumen dengan tepat. NV berusaha mengeksplor dan menjelaskan secara detail maksud dari soal yang diberikan.

Hasil pengamatan peneliti di lapangan didapatkan bahwa NV berusaha menggali ide untuk mendapatkan pemahaman dari suatu masalah yang dihadapi. Ia mau mencoba secara sungguh-sungguh kemungkinankemungkinan yang mungkin terjadi pada soal yang dihadapinya sehingga ia mampu memecahkan masalah.

\section{Penutup}

Jenis antisipasi yang dilakukan NV dalam menyelesaikan masalah integral ini adalah antisipasi eksplorasi dimana NV menguraikan soal secara detail dan melaksanakan kegiatan menyelesaikan masalah secara rinci. Sehingga karakteristik yang dapat kita peroleh dalam penelitian ini adalah:

1. membaca soal lebih dari satu kali

2. menemukan hal yang ditanyakan dan hal yang diketahui

3. menguraikan soal secara rinci

4. menggabungkan kriteria-kriteria yang diketahui

5. memecahkan soal dengan mempertimbangkan alternatif penyelesaian 


\section{Daftar Pustaka}

Anderson, J. R. (1993). Rules of the mind. American Psychologist. Hillsdale, NJ 07642: Lawrence Erlbaum Associates, Inc. https://doi.org/10.4324/97813158069 38

Lim, K. H. (2006). Characterizing students' thinking: Algebraic, inequalities and equations. Proceedings of the 28th Annual Meeting of the North American Chapter of the International Group for the Psychology of Mathematics Education, 2(c), 102-109.

Ramdani, Y. (2012). Pengembangan Instrumen dan Bahan Ajar untuk Meningkatkan Kemampuan
Komunikasi, Penalaran, dan Koneksi Matematis dalam Konsep Integral. Jurnal Penelitian Pendidikan, 13(1), 44-52. Retrieved from http://jurnal.upi.edu/file/6yani_ramdhana-edi.pdf Yudianto, E. (2015). Profil Antisipasi Siswa SMA dalam Memecahkan Masalah Integral. Kreano, 6(1), 2125 .

https://doi.org/http://dx.doi.org/10.15 294/kreano.v6i1.4472

Yudianto, E., \& Sunardi. (2015). Antisipasi Siswa Level Analisis dalam Menyelesaikan Masalah Geometri. AdMathEdu, 5(2), 203216. 